ВЗАЄМОЗВ'ЯЗОК ЕМОЦІЙНОГО ІНТЕЛЕКТУ ЗІ СТИЛЕМ МАТЕРИНСЬКОГО СТАВЛЕННЯ У ЖІНОК, ЯКІ ВИХОВУЮТЬ ДІТЕЙ ІЗ ВІДХИЛЕННЯМИ У ПСИХОФІЗИЧНОМУ РОЗВИТКУ

\title{
RELATIONSHIP BETWEEN EMOTIONAL INTELLIGENCE AND THE STYLE OF MOTHER'S ATTITUDE IN WOMEN RAISING CHILDREN WITH PSYCHOPHYSOPHICAL DEVIATIONS
}

В Україні, як і в усьому світі, невпинно зростає кількість дітей з вадами розвитку. Для розвитку такої дитини спеціальним корекційно-розвиваючим середовищем є сім'я та материнсько-дитячі відносини, які можуть бути порушені в стресогенній ситуації виховання дитини 3 особливими потребами. Актуальним $\epsilon$ дослідження, спрямоване на пошук методів розкриття потенціалу особистості матері для виховання та соціалізації дитини, адже процеси формування материнської поведінки у разі відхилень у розвитку дитини досліджені недостатньо. Огляд сучасних наукових першоджерел показує, що емоційний інтелект постає домінуючим і системоутворюючим конструктом поведінки особистості в стресогенній ситуації, але вплив емоційного інтелекту матері на ії взаємодію з дитиною з особливими потребами вивчений недостатньо.

Метою статmі $\epsilon$ дослідження та аналіз взаємозв'язку складників емоційного інтелекту та особливостей материнсько-дитячої взаємодії у сім'ях, де виховуються діти з особливими потребами. У статmі досліджене поняття «материнське ставлення» (далі - МС) як інтегральна характеристика прояву материнської поведінки у взаємодії 3 дитиною та з оточенням. Вчені визначають 5 таких стилів МС: адекватний, тривожний, амбівалентний, емоційно відсторонений та афрективно відторгуючий. Новизна роботи полягає в тому, ми розглядаємо вплив складників емоційного інтелекту на формування конкретного стилю МС до дитини з особливими потребами. Для визначення стилю МС застосовано авторський опитувальник (ОМС) Л.О. Зіборової, Т.В. Дегтяренко. Обстежено 120 матерів, серед яких у 34,3\% виявлено адекватний стиль МС, у 25,7\% тривожний стиль МС, у 21,4\% - амбівалентний стиль МС, а 18,6\% жінок мають емочійно відсторонений стиль МС. Афрективно відторгуючий стиль не був діагностований у матерів дітей з особливими потребами. Для емпіричного дослідження складників емоційного інтелекту матерів, які виявили різні стилі материнського ставлення (MC) до дитини з особливими потребами, застосовано опитувальник "EmIn" Д.В. Люсіна.

Ключові слова: емоційний інтелект, стресозахисна та адаптивна функція емоційного інтелекту, стиль материнського ставлення, материнсько-дитячі відносини.
In Ukraine, as in the world, the number of children with disabilities is steadily growing. For the development of such a child, a special correctional and developmental environment is, first of all, the family and the mother-child relationship, which can be disrupted in a stressful situation of raising a child with special needs. Research aimed at finding methods to reveal the potential of the mother's personality for the upbringing and socialization of the child is relevant, because the processes of formation of maternal behavior with abnormalities in the child's development are insufficiently studied. A review of modern scientific sources shows that emotional intelligence is the dominant system-forming construct of personality behavior in a stressful situation, but the influence of emotional intelligence of the mother on her interaction with a child with special needs is not defined enough.

The purpose of this article is to study and analyze the relationship between the components of emotional intelligence and the peculiarities of maternal-child interactions in the special needs of the child. The article explores one of the main concepts of motherhood - maternal attitude (hereinafter MA), as an integral characteristic of the manifestation of maternal behavior in interaction with the child and the environment as a mother. There are 5 styles of MA: adequate, anxious, ambivalent, emotionally detached and affectively repulsive. The novelty of this work lies in the fact that the influence of the level of components of emotional intelligence on the formation of a particular style of MA to a child with special needs is considered. To determine the style of MA used author's questionnaire (MRQ) L.O. Ziborova, T.V. Degtyarenko. 120 mothers were examined, among whom 34.3\% had an adequate MA style, $25.7 \%$ had an anxious $M A$ style, $21.4 \%$ had an ambivalent MA style, and $18.6 \%$ of women had an emotionally detached MA style. Affective-rejection style has not been diagnosed in mothers of children with special needs. For the empirical study of the components of emotional intelligence of mothers who found different styles of maternal attitude (MA) to the child with special needs, the questionnaire "EmIn" D.V. Lucin.

Key words: emotional intelligence, stress-protective and adaptive function of emotional intelligence, style of maternal attitude, maternal-child relations.
Фактори економічної та соціальної нестабільності сучасного суспільства збільшують труднощі виховання дітей у сім'ях. Особливі проблеми у сім'ї виникають у разі народження дитини з відхиленнями розвитку. Формування базових основ психіки дитини визначається особливостями материнсько-дитя- чих відносин у сім'ї, які залежать від прояву властивостей особистості матері в конкретній життєвій ситуації. Народження дитини з відхиленнями у розвитку є травмуючою ситуацією в житті матері. Така ситуація може впливати на видозмінення материнської особистісної сфери жінки та її материнського ставлення 
(далі - МС). 3 огляду на це особливої актуальності набувають дослідження прояву властивостей особистості жінки в стресогенній ситуації народження дитини з вадами психофізичного розвитку.

У сучасних дослідженнях життєдіяльності особистості однією з найважливіших характеристик як диспозиційних, так і безпосередньо поведінкових аспектів функціонування людини як суб'єкта життєдіяльності визначається емоційність. Актуальність дослідження впливу емоційності за різних умов життедіяльності особистості зумовлена як соціальним запитом на подолання найвищого з усіх часів людства рівня емоційної нестриманості на усіх рівнях соціуму, так і прагненням фахівців в галузі психофізіології, диференційної психології особистості дослідити стан емоційних процесів людини в умовах стресогенної ситуації.

В останне десятиріччя плідним науковим напрямом стало дослідження впливу емоційного інтелекту (далі - ЕІ) особистості на її поведінку в емоціогенній ситуації. Вивчення особливостей впливу емоційного інтелекту на поведінку матері в стресогенній ситуації аномальності розвитку дитини необхідне для вироблення шляхів і способів оптимізації материнського ставлення до дитини з особливими потребами.

Поняття «емоційний інтелект», введене Дж.Д. Майером та П.С. Саловей, означає гармонійне поєднання емоційного та раціонального, що відображає уміння сприймати, оцінювати, ідентифікувати, розуміти та генерувати емоції таким чином, щоб допомагати мисленню, а також рефлекторно керувати емоціями так, щоб сприяти власному розвитку.

Дослідження І.М. Андрєєвої, О.В. Власової, Д. Карузо, Дж.Д. Майера, М.А. Нгуєн, Р. Робертса, О.М. Приймаченко дозволили виокремити в структурі емоційного інтелекту п'ять таких складників: 1) спроможність усвідомити власні емоції, що дає людині можливість краще впоратись з ними. Ця складова частина $€$ провідною в емоційному інтелекті (ВР); 2) регулювання та контроль над власними емоціями, здібність долати негативні емоційні стани (ВУ); 3) спроможність налаштовувати себе на діяльність, тобто самомотивування (BE); 4) здібність до розуміння емоцій інших людей, виявлення емпатії (MP); 5) вміння проявляти емпатію, підтримувати доброзичливі стосунки з іншими людьми, позитивне ставлення до інших (МУ). У роботах І.Ф. Аршава, Р. Бар-Она, М.А. Брекетта, Н.В. Ковриги, Е.Л. Носенко, Г.В. Юсупової досліджено вплив емоційного інтелекту на соціально-психологічну адаптацію особистості та доведено, що вищенаведені складові структури емоційного інтелекту охоплюють всі емоційні аспекти функціонування людини. Е.Л. Носенко та Н.В. Коврига зазначають: «Фактично компоненти емоційного інтелекту людини є системоутворювальними факторами особистості. Вони зумовлюють стабільність емоційних переживань людини, її схильність до переживання позитивних або негативних процесів, у формі яких відображається оцінювання людиною всіх аспектів її життєдіяльності» [4, с. 18].

Стресозахисна та адаптивна функції емоційного інтелекту визначаються змістом його складників. У сучасних дослідженнях емоційний інтелект розглядається як інтегральна особистісна властивість, яка визначає стиль поведінки людини в емоціогенних ситуаціях та має розглядатися в контексті адаптивності особистості (Е.Л. Носенко, Н.В. Коврига). Особлива роль рівня розвиненості емоційного інтелекту матері у материнсько-дитячій взаємодії, формуванні емоційних механізмів дитини та створенні моделі сприйняття світу дитиною розглянута у роботах С. Герхардт та Д. Гоулмена. Слід зауважити, що у вітчизняній спеціальній психології немає досліджень впливу емоційного інтелекту на формування стилю материнського ставлення до дитини з особливими потребами. Наша робота $є$ спробою розглянути механізми формування стилю материнського ставлення до дитини з особливими потребами як прояви системоутворювальної інтегративної властивості особистості - емоційного інтелекту.

Мета роботи - дослідження ролі емоційного інтелекту у формуванні особливостей материнського ставлення у жінок, які виховують дітей з вадами психофізичного розвитку.

Емоціогенною ситуацією в житті жінки може виступати народження дитини з вадами психофізичного розвитку. До теперішнього часу в психологічних дослідженнях не було аналізу формування модифікованої материнської поведінки у разі народження аномальної дитини з позицій прояву складників та функцій емоційного інтелекту жінки як провідної й системоутворювальної властивості її особистості, що має прояв у широкому спектрі ситуацій. Розглянемо вплив складників емоційного інтелекту на особливості моделювання матір'ю певного стилю материнського ставлення до дитини з особливими потребами.

Стиль материнського ставлення у матері дитини з особливими потребами формується в умовах незадоволених потреб материнської сфери та стресогеннихчинників - психотравми від порушень розвитку дитини та психотравми від порушення очікуваної ролі успішної матері. У такому разі мати здійснює регуляцію власних емоцій свідомо або підсвідомо. Індивідуальні рівні складників емоційного інтелекту впливають на материнську поведінку жінки, яка виховує дитину з особливими потребами, 
та виявляють різні особливості материнського ставлення.

Адекватний стиль материнського ставлення до здорової дитини вміщує природну та радісну реакцію матері на приємні для неї стимули дитини. У разі адекватного материнського ставлення до дитини 3 особливими потребами мати починає стримувати негативні емоції (біль, відчай, страждання від незвичного вигляду дитини) та підсилювати і демонструвати дитині позитивні емоції, тому що вона відчуває потребу дитини в позитивних емоціях. Мати намагається адаптувати свою поведінку до потреб дитини та захистити себе та дитину від стресу, тобто моделює свою поведінку. Адекватність взаємодії в діаді «мати - дитина» забезпечується достатньо розвиненим емоційним інтелектом жінки, активним застосуванням складників емоційного інтелекту в регуляції власних емоцій. Якщо емоційний інтелект жінки недостатньо розвинений, вона не може продуктивно стримувати негативні емоції та транслювати позитивні емоції. У такому разі мати перебуває в тривожному стані і формує тривожну прив'язаність до дитини.

Амбівалентний стиль відображає намагання жінки моделювати позитивні емоції, які виявляються нестійкими через емоційну нестабільність та низький рівень емоційного інтелекту, адже жінка не дуже чітко ідентифікує власні емоції, тому вона не може їх регулювати.

Емоційно відсторонений стиль материнської поведінки демонструють жінки з нерозвиненим емоційним інтелектом. Як правило, ці жінки транслюють емоційно відсторонений стиль виховання, який проявляли їхні батьки. За наявності ознак порушення розвитку у дитини такі жінки захищаються від негативних емоцій лише тим засобом, який їм доступний, тобто ще більшою емоційною відстороненістю від дитини.

При афективно відторгуючому стилі поведінки матері $є$ безсилими перед неконтрольованим потоком власних негативних емоцій, тому вони відторгують дитину як негативний подразник.

Ознаки певного стилю материнської поведінки в ситуації наявності відхилень у розвитку дитини повною мірою відповідають ступеню розвиненості емоційного інтелекту жінки. Критерії, сформульовані Г.Г. Філіпповою для відокремлення стилів материнського відношення, відображають зміст основних п'яти складників емоційного інтелекту [5, с. 208]. Серед критеріїв материнського ставлення визначальними є такі: 1) стиль емоційного супроводу, що $є$ здібністю матері ідентифікувати та регулювати власні емоції; 2) рівень розвитку та швидкість проявлення материнської компетентності; 3) пристосування до нового ритму життя, засвоєння нових обов'язків, що є проявом у новій життєвій ситуації такої складової частини емоційного інтелекту, як спроможність налаштувати себе на діяльність (самомотивування); 4) пристосування режиму життя сім'ї до індивідуального ритму дитини. Створення гармонійної атмосфери у сім'ї відображає здібність жінки розуміти емоції інших людей, виявляти емпатію; 5) задоволення ставленням до себе і до дитини з боку інших людей, що цілком залежить від уміння жінки розпізнавати емоції інших, позитивно ставитися до інших.

Зіставлення критеріїв стилю материнського ставлення та змісту складників емоційного інтелекту показує, що регулятивні функції емоційного інтелекту впливають на формування стилю материнського ставлення жінки у стресогенній ситуації виховання дитини з особливими потребами як системоутвюрюючі механізми.

Для емпіричного дослідження складників емоційного інтелекту матерів, які виявили різні стилі материнського ставлення (MC) до дитини з особливими потребами, ми застосували опитувальник "Emln” Д.В. Люсіна. Для визначення стилю МС ми застосували авторський опитувальник «Опитувальник материнського ставлення» (ОМС) Л.О. Зіборової, Т.В. Дегтяренко.

Обстежено 120 матерів, серед яких у 34,3\% виявлено адекватний стиль МС (група А), у 25,7\% - тривожний стиль МС (група Т), у 21,4\% - амбівалентний стиль МС (група Б), а 18,6\% жінок мають емоційно відсторонений стиль МС (група Е). Афективно відторгуючий стиль не був діагностований [3, с. 192].

Результати діагностики наведено у таблиці 1.

Результати, наведені в таблиці 1, показують, що жінки групи А виявили високий рівень розуміння власних емоцій (24,43 бала). За словами Д. Гоулмена, розуміння власних емоцій - наріжний камінь емоційного інтелекту. Вчений зазначає: «Вміння розбиратися у власних емоціях є основоположною емоційною компетенцією, тобто здатністю, на базі якої формуються усі інші складники емоційного інтелекту» [2, с. 99]. Відповідно до такого висновку рівень керування власними емоціями у жінок групи А становить 17,05 бала, що $є$ високим значенням за методикою, як і показник контролю експресії, який становить 13,71 бала. Разом ці три показники забезпечують головну потребу материнсько-дитячої взаємодії з дитиною з особливими потребами - потребу в моделюванні адекватної емоційної взаємодії з дитиною, яка можлива лише у разі розвиненої здатності матері до ідентифікації власних емоцій, здатності викликати та транслювати бажані емоції та утримувати під контролем небажані. Вищезазначені емоційні 
Результати діагностики емоційного інтелекту в групах А, Т, Б та E

Таблиця 1 за методикою "EmIn” Д.В. Люсіна

\begin{tabular}{|c|c|c|c|c|c|c|c|c|c|}
\hline $\begin{array}{c}\text { Складники } \\
\text { емоційного } \\
\text { інтелекту }\end{array}$ & Група А & Група Т & $\begin{array}{c}\text { t- } \\
\text { критерій }\end{array}$ & Група Т & Група Б & $\begin{array}{c}\text { t- } \\
\text { критерій }\end{array}$ & Група Б & Група Е & $\begin{array}{c}\text { t- } \\
\text { критерій }\end{array}$ \\
\hline $\mathrm{BP}$ & 24,43 & 14,07 & $10,33^{\star \star \star}$ & 14,07 & 11,62 & $5,11^{\star \star \star}$ & 11,62 & 2,36 & $7,75^{\star \star \star}$ \\
\hline By & 17,05 & 9,87 & $12,72^{\star \star \star}$ & 9,87 & 7,38 & $3,47^{\star \star \star}$ & 7,38 & 3,27 & $9,39^{\star \star \star}$ \\
\hline $\mathrm{BE}$ & 13,71 & 8,73 & $10,41^{\star \star \star}$ & 8,73 & 6,62 & $5,09^{\star \star \star}$ & 6,62 & 5,27 & $3,27^{\star \star}$ \\
\hline MP & 26,67 & 16,13 & $10,17^{\star \star \star}$ & 16,13 & 12,42 & $4,79^{\star \star}$ & 12,42 & 2,14 & $5,45^{\star \star \star}$ \\
\hline МП & 25,67 & 13,80 & $11,70^{\star \star \star}$ & 13,80 & 9,19 & $9,27^{\star \star \star}$ & 9,19 & 4,23 & $10,37^{\star \star \star}$ \\
\hline
\end{tabular}

Примітки: * - статистична достовірність розбіжностей на рівні $\mathrm{p} \leq 0,05$; ** - статистична достовірність розбіжностей на рівні $\mathrm{p} \leq 0,01 ;{ }^{\star \star \star}$ - статистична достовірність розбіжностей на рівні $\mathrm{p} \leq 0,001$.

компетенції матері дитини з особливими потребами проявляються в адекватному (оптимальному) стилі материнського ставлення, що вміщує відтворення емоцій, які жінка може не відчувати у цей час, але вважає за необхідне їх проявляти у взаємодії з дитиною. Д. Гоулмен зазначає: «Здатність утримувати емоційний порив $€$ сутністю емоційної саморегуляції» [2, с. 160]. Здатність до моделювання та трансляції позитивних емоцій допомагає матері дитини з особливими потребами в оптимальному виконанні найважливіших материнських функцій - збереження емоційного благополуччя дитини та навчання дитини основам емоційного інтелекту. Д. Гоулман пише: «Життя у сім'ї - наша перша школа емоційного навчання. У її закритому котлі дитина вчиться тому, як ставитися до себе, як інші реагують на наші переживання. Що думати про ці переживання, які є засоби виражати надії та страхи - цьому дитина вчиться у батьків, зокрема у матері» [2, с. 337]. Відносини дитини 3 оточенням емоційно обізнана мати також моделює через використання здатності розуміти емоції інших та регулювати ці емоції. У жінок групи А розуміння емоцій інших (26,67 бала), як і здатність керувати емоціями інших (25,67 бала), є високим. Жінки групи А здатні до регуляції відносин з іншими навіть у конфліктних ситуаціях, що $€$ передумовою виховання довіри до світу у дитини.

Показники складників емоційного інтелекту у жінок групи Т з високим ступенем статистичної достовірності відрізняються від показників жінок групи А. Низькі рівні розуміння власних емоцій (14,07 бала), керування власними емоціями (9,87 бала) та контролю експресії (8,73 бала) не дозволяють жінкам групи Т чітко ідентифікувати власні емоції, тому вони відчувають тривогу та безсилля змінити відносини з дитиною. Д. Гоулман у своїй монографії виокремлює таких людей як тих, що сприймають негативні емоції як щось неминуче. Вони страждають через дистрес, а фактор безпомічності створює надсильну загрозу для них [2, с. 101]. Нездатність до розуміння та регу- лювання власних емоцій, підвищена сенситивність та страх за дитину викликають у тривожних матерів бажання всіляко захищати дитину з особливими потребами від стресів. У дослідженні впливу поведінки матері на лякливих та сором'язливих дітей I. Кейган зробив такий висновок: «матері, які захищають своїх надмірно реактивних дітей від розладів та тривожності в надії на досягнення сприятливого результату, лише підсилюють невпевненість дитини та викликають протилежний ефект» [2, с. 394]. Захисна стратегія тривожних матерів відбирає у дитини можливість навчитися заспокоюватися у невідомій ситуації і хоч якось опановувати страх, унаслідок чого лякливість та занепокоєння дитини лише підсилюються, а мати ще більше відчуває безсилля.

У таблиці 1 видно, що між матерями груп Т та Б статистично достовірні розбіжності існують за всіма показникам складників емоційного інтелекту, але значення t-критерію $€$ значно меншими, ніж у разі порівняння показників груп А та Т. Відмінності показників груп Т та Б також $є$ значно меншими, ніж відмінності між показниками груп А та Т. Рівні розуміння власних емоцій $(11,62$ бала), керування емоціями (7,38 бала) та контролю експресії (6,62 бала) за методикою $є$ дуже низькими, тобто жінки групи Б слабко усвідомлюють емоційні стани як у себе, так і в інших, вони не здатні контролювати власні емоції, що призводить до того, що емоції поглинають жінок. Такі люди не можуть подолати негативні емоції, наче настрій керує ними, а не навпаки. Вони не усвідомлюють почуттів, повністю занурені у них та не можуть уникнути негативного настрою, що ще більше дратує їх. Взаємодію таких матерів з дитиною досліджено у монографії С. Герхардт. Вона зазначає: «Якщо мати не навчилася регулювати власні негативні почуття, їй буде важко витримувати їх прояви у дитини. Вона може відчувати сильний стрес, дискомфорт та бажання скоріше позбутися цих почуттів, не розбираючись в них, що може проявлятися як гнів, ворожість та агресія щодо дитини» $[1$, с. 44]. Матері з низьким емоційним 
інтелектом дуже мінливі у власних реакціях на почуття дитини: іноді вони турбуються про дитину, а іноді вони ігнорують емоції дитини або виявляють гнів. У дослідженні С. Герхардт сказано: «Дитина перебуває у розгубленому стані. Дитина з часом усвідомлює, що вона не отримує допомоги у відновленні комфортного стану, вона може намагатися витіснити, виключити негативні почуття, але не вміє цього робити, тому вона постійно перебуває у стані надмірного усвідомлення власних страхів та потреб, що блокує її розвиток» [1, с. 45]. Наведені висновки дослідниці підтверджують руйнівний вплив проявів низької емоційної компетентності матері на формування емоційних механізмів дитини, який може лише підсилюватися за наявності відхилень у психофізичному розвитку дитини.

Усі показники складників емоційного інтелекту жінок групи Е з високим ступенем статистичної достовірності відрізняються від показників жінок групи Б та є дуже низькими. Емоції як маркери психотравмуючої ситуації не сприймаються такими жінками, тому вони не здатні адекватно оцінювати загрози відхилень у психофізичному розвитку для майбутнього дитини, не відчувають емоційних потреб дитини, поводяться з дитиною відсторонено та беземоційно. Чинники емоційно відстороненої поведінки матерів привертають увагу дослідників, але вони вивчені недостатньо.

Отримані результати демонструють, що у матерів, які проявляють різні стилі материнського ставлення до дітей з особливими потребами, найбільші відмінності виявлені у показниках розуміння власних емоцій та розуміння емоцій інших. Зазначені властивості $€$ основоположними в емоційній компетентності людини. Саме такі показники найбільше диференціюють групи матерів особливих дітей за стилем материнського ставлення. У матерів дітей з особливими потребами був виявлений широкий діапазон рівнів складників емоційного інтелекту. Це визначає можливі варіанти формування життєвої моделі дитини - від розвиненої здатності емоційного регулювання та соціалізації до емоційної безпорадності та соціальної ізоляції.

Ми дійшли таких висновків:

1) введення поняття емоційного інтелекту, виділення його функцій та складових частин дозволяє розглядати прояви поведінки людини в різних ситуаціях як динамічні процеси, що зумовлені емоційністю людини та спрямовані на захист від стресу і адаптацію в стресогенній ситуації. Виявлені складники та функції емоційного інтелекту показують, що емоційний інтелект $є$ системоутворюю- чим фактором особистості, який визначає стиль поведінки людини в стресогенній ситуації;

2) народження та виховання дитини з відхиленнями у розвитку $є$ стресогенною ситуацією у житті жінки. Поведінка матері може видозмінюватись, тому що порушення ключових стимулів материнства та психотравма матері негативно впливають на особливості материнського ставлення. Стиль материнського ставлення набуває емоційної та соціальної дефіцитарності, що негативно впливає на розвиток дитини;

3) проведене дослідження за авторським опитувальником визначення стилю материнського ставлення ОМС виявило розподіл 120 матерів дітей з особливими потребами на такі групи: група А відповідає адекватному стилю материнського відношення (34,3\%); групу Т становлять жінки з тривожним стилем материнського відношення $(25,7 \%)$; група Б відповідає амбівалентному стилю материнського відношення $(21,4 \%)$; група Е відповідає емоційно відторгуючому стилю материнського відношення (18,6\%). Дослідження за опитувальником Д.В. Люсіна показало, що жінки 3 адекватним стилем МС мають високі показники усіх складників емоційного інтелекту. Жінки групи Т виявили низькі, майже вдвічі менші, ніж у групі А, показники емоційного інтелекту. Найменші показники ЕІ виявлено у жінок групи Е. Емпирічне дослідження підтвердило системоутворювальний вплив складників емоційного інтелекту на стиль материнського ставлення до дитини з особливими потребами;

4) аналіз теоретичнихдослідженьтапсиходіагностичне обстеження матерів дітей з особливими потребами доводять, що за наявності відхилень у психофізичному розвитку дитини стиль материнського ставлення моделюється за допомогою регулювання матір'ю прояву власних емоцій. Емоційна стійкість та розвинений емоційний інтелект дозволяють матері ідентифікувати та регулювати власні емоції. У разі нерозвиненого емоційного інтелекту матері не можуть регулювати потік негативних емоцій і забезпечити адекватний супровід дитини. Дослідження доводить, що бажане підвищення рівня емоційного інтелекту відповідає потребам матерів дітей з особливими потребами та буде сприяти оптимізації материнсько-дитячих відносин. Актуальними $€$ подальше дослідження особливостей емоційного інтелекту матерів дітей з особливими потребами та розробка спеціальних методик розвитку емоційної обізнаності жінок в контексті оптимізації стилю материнського ставлення. 


\section{ЛIТЕРАТУРА:}

1. Герхардт С. Как любовь фрормирует мозг ребенка/пер. сангл. Ю.В. Рыковский. Москва:Этерна, 2012. $320 \mathrm{c}$.

2. Гоулман Д. Эмоциональный интеллект / пер. с англ. А. Исаевой Москва : Манн, Иванов и Фербер, 2013. $560 \mathrm{c}$.

3. Зіборова О.О. Визначення стилю материнського відношення у жінок, які мають дитину 3 вадами розвитку. Інтеграція науки і практики в умо- вах модернізації корекційної освіти України : збірник наукових праць Всеукраїнської науково-практичної консреренції. Херсон : ПП «Вишемирський В.С.», 2014. 282 c.

4. Носенко Е.Л., Коврига Н.В. Емоційний інтелект: концептуалізація феномену, основні фуннкції. Київ : Вища школа, 2003. 126 с.

5. Филиппова Г.Г. Психология материнства. Москва : Ин-т психотерапии, 2002. 239 с. 